\title{
Synthesis, Characterization and Antimicrobial Activity of Transition Metal Complexes of Schiff Base Ligand Derived from 3-Ethoxy Salicylaldehyde and 2-(2-Aminophenyl) 1-H-benzimidazole
}

\author{
MATANGI SUNITHA*, PRAGATHI JOGI, BATHINI USHAIAH, AND \\ C. GYANA KUMARI* \\ *Department of Chemistry, Osmania University, Hyderabad-500 007, India \\ sunitha.chem@gmail.com
}

Received 19 December 2011; Accepted 27 February 2012

\begin{abstract}
Metal complexes of $\mathrm{Ni}(\mathrm{II}), \mathrm{Co}(\mathrm{II}), \mathrm{Cu}(\mathrm{II}), \mathrm{Mn}(\mathrm{II})$ and $\mathrm{Zn}(\mathrm{II})$ VO(IV) with a Schiff base derived from 3-Ethoxy Salicylaldehyde and 2-(2amino-phenyl) $1-H$-Benzimidazol(2-[(Z)-\{(2-(1H-benzimidazole-2yl)phenyl $]$ imino methyl]-6-ethoxy phenol-BMEP) were synthesized successfully. The resulting complexes were characterized by elemental analysis, magnetic moment measurements, conductivity measurements, IR, UV-VIS, ${ }^{1} \mathrm{H}$ NMR, mass spectra and ESR spectral studies. According to these data, we propose an octahedral geometry to all the metal complexes. Antimicrobial activity of the ligand and its metal complexes were studied against two gram negative bacteria: E. Coli, Pseudomonas flourescence and two gram positive bacteria: Bacillus subitilis, Staphylococcus aureus. The activity data show that the metal complexes are more potent than the free ligand.
\end{abstract}

Keywords: Schiff base, 3-Ethoxysalicylaldehyde, 2-(2-Aminophenyl)1- $H$ - benzimidazole, Metal complexes, Bacteria.

\section{Introduction}

In the field of coordination chemistry, Schiff base metal complexes have a curious history ${ }^{1,2}$. Metal ions play vital roles in the vast number of biological processes. Metal complexes with Schiff base ligands have been studied for their application in biological, clinical, analytical and pharmacological areas ${ }^{3}$.

Benzimidazoles are very useful intermediates for the development of Molecules of biological interest. Substituted benzimidazole derivatives have found applications in antifungals, anticancers and antiulcers $e t c^{4,5}$. In this paper efforts were taken for the synthesis, characterization and antimicrobial studies of transition metal Complexes of bidentate nature 
of the ligand which coordinates through the tertiary nitrogen of the imidazole ring, the exocyclic imine nitrogen of 2-(2-aminophenyl)1- $H$ - benzimidazole.

\section{Experimental}

All chemicals and solvents used in this work were Analytical grade. 2-(2- aminophenyl)1- $H$ benzimidazole and 3-ethoxy salicylaldehyde was of Sigma Aldrich chemicals.Vanadyl sulphate, Copper chloride, Nickel chloride, Zinc chloride, Manganese chloride and Cobalt chloride, DMSO, of SD's fine chemicals.

\section{Instrumentation}

The percentage compositions of $\mathrm{C}, \mathrm{H}$ and $\mathrm{N}$ of complexes were determined by using micro analytical methods of PerkinElmer 240 (USA) elemental analyzer. Infrared spectra of ligands and their complexes were recorded on Perkin Elmer Infrared model 337 spectrometer in $\mathrm{KBr}$ pellets in the range of (4000-400 cm-1). The UV-Visible spectra were recorded on a Schimadzu UV spectrometer in the wavelength range $200-1100 \mathrm{~nm}$. The mass spectra were recorded by ESI technique on VG AUTOSPEC mass spectrometer instrument. The ${ }^{1} \mathrm{H}$ NMR spectra was recorded on Varian Gemini Unity Spectrometer by employing TMS as internal standard. Melting points of the ligand and decomposition temperature of complexes were determined on Polmon instrument (model No.MP-96). The Molar conductance measurements were carried out in DMSO $\left(10^{-3} \mathrm{M}\right)$ using Digisun Electronic Digital conductivity meter of model: DI-909 having a dip-type cell calibrated with $\mathrm{KCl}$. The Magnetic susceptibilities of complexes were determined on Gouy balance model 7550 at $23{ }^{\circ} \mathrm{C}$. The diamagnetic corrections were made by Pascal's constant and $\mathrm{Hg}\left[\mathrm{Co}(\mathrm{SCN})_{4}\right]$ was used as a calibrant..Electro spin resonance spectra of powered $\mathrm{Cu}(\mathrm{II})$, complex was recorded on JOEL.TE -3X .X-Band spectrometer.

\section{Synthesis of Schiff base}

A mixture of 2-(2-aminophenyl)1- $H$-benzimidazole $(2.09 \mathrm{~g} ; 0.01 \mathrm{~mol})$ and 3-ethoxy salicylaldehyde (1.66 g; $0.01 \mathrm{~mol})$ and a drop of acetic acid was dissolved in $25 \mathrm{~mL}$ of ethanol and heated on a steam bath for 45-60 min. The reaction mixture was allowed to stand at room temperature for $24 \mathrm{~h}$, the yellow solid product was separated out and dried under vacuum at room temperature.

Structure of the Schiff base is shown below

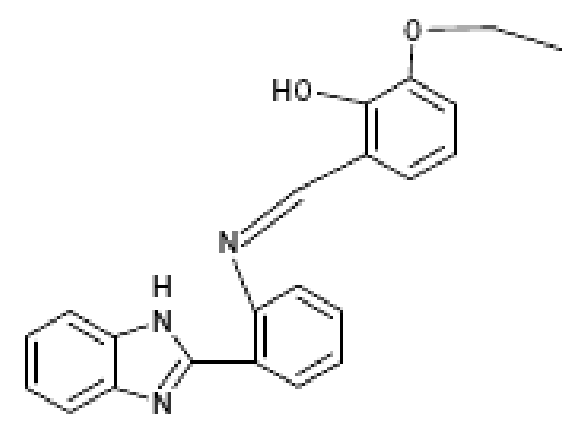

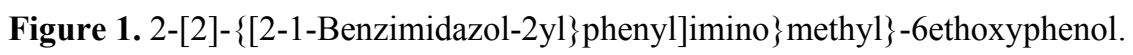

\section{Synthesis of metal complexes}

Hot ethanolic solution of ligand $(0.005 \mathrm{~mol})$ and ethanolic solution of corresponding metal salts $(0.005 \mathrm{~mol})\left(\mathrm{MX}_{2}\right.$, where $\mathrm{M}=\mathrm{Ni}(\mathrm{II}), \mathrm{Co}(\mathrm{II}), \mathrm{Cu}(\mathrm{II}) \mathrm{Zn}(\mathrm{II})$ and $\mathrm{Mn}$ (II) $\mathrm{VO}(\mathrm{IV})$ $\mathrm{X}=\mathrm{Cl} / \mathrm{So}_{4} /$ acetates) were stirred constantly. The resulting solution was boiled under reflux 
for 4-5 hrs and then left to cool. The precipitated complex was filtered off, washed with anh.ethanol and dried in vacuum at room temperature.

\section{Results and Discussion}

\section{Physical properties}

All the complexes are stable at room temperature and are non-hygroscopic. On heating, they decompose at high temperatures. The complexes are insoluble in water but are soluble in DMSO. The analytical data and physical properties of the ligand and complexes are summarized in table 1.

\section{Elemental analysis}

It is clear from the data that the experimental values shown for each of the compound are in good agreement with the theoretical values calculated for 1:1 ratio. The composition assigned to the ligand and its complexes may, therefore be formulated as presented in Table 1.

\section{Molar conductance}

The Molar Conductance of metal complexes were measured using $10^{-3} \mathrm{M}$ DMSO solvent, the obtained values (Table 1) suggest the presence of a non-electrolytic nature ${ }^{11}$ and that no anions are present outside the coordination sphere.

Table 1. Analytical data and physical properties of the ligand and its complexes.

\begin{tabular}{|c|c|c|c|c|c|c|c|c|c|}
\hline Compound & $\begin{array}{c}\text { Emperical } \\
\text { Formula }\end{array}$ & $\begin{array}{l}\text { Mol. } \\
\text { Wt. }\end{array}$ & $\begin{array}{l}\text { M.P, } \\
{ }^{\circ} \mathrm{C}\end{array}$ & $\begin{array}{c}\text { Yiel } \\
\mathrm{d} \\
(\% 2)\end{array}$ & $\begin{array}{c}\text { C } \\
\text { Found } \\
\text { (Calc.) }\end{array}$ & $\begin{array}{c}\mathrm{H} \\
\text { Found } \\
\text { (Cc.) }\end{array}$ & $\begin{array}{c}\mathrm{N} \\
\text { Found } \\
\text { (Calc.) }\end{array}$ & $\begin{array}{c}\mathrm{M} \\
\text { Found } \\
\text { (Calc.) }\end{array}$ & $\begin{array}{c}\Omega \\
\mathrm{Ohm}^{-1} \\
\mathrm{~cm}^{2} \mathrm{~mol}^{-1}\end{array}$ \\
\hline $\begin{array}{l}\text { Ligand } \\
\text { (BMEP) }\end{array}$ & {$\left[\mathrm{C}_{22} \mathrm{H}_{19} \mathrm{~N}_{3} \mathrm{O}_{2}\right]$} & 357 & 155 & 95 & $\begin{array}{l}73.23 \\
(73.9)\end{array}$ & $\begin{array}{c}5.28 \\
(5.32)\end{array}$ & $\begin{array}{c}11.54 \\
(11.76)\end{array}$ & & \\
\hline $\begin{array}{c}\mathrm{Cu}(\mathrm{II}) \\
\text { Complex }\end{array}$ & $\begin{array}{c}{\left[\mathrm{CuC}_{22} \mathrm{H}_{23}\right.} \\
\left.\mathrm{N}_{3} \mathrm{O}_{4} \mathrm{Cl}_{2}\right]\end{array}$ & 527.5 & 195 & 85 & $\begin{array}{c}50.18 \\
(50.04)\end{array}$ & $\begin{array}{c}4.33 \\
(4.36)\end{array}$ & $\begin{array}{c}7.95 \\
(7.96)\end{array}$ & $\begin{array}{c}12.01 \\
(12.12)\end{array}$ & 28 \\
\hline $\begin{array}{c}\mathrm{Ni}(\mathrm{II}) \\
\text { Complex }\end{array}$ & $\begin{array}{l}{\left[\mathrm{NiC}_{22} \mathrm{H}_{23}\right.} \\
\left.\mathrm{N}_{3} \mathrm{O}_{4} \mathrm{Cl}_{2}\right]\end{array}$ & 522 & $>300$ & 65 & $\begin{array}{c}50.05 \\
(50.57)\end{array}$ & $\begin{array}{c}4.31 \\
(4.40)\end{array}$ & $\begin{array}{c}8.10 \\
(8.04)\end{array}$ & $\begin{array}{c}11.00 \\
(11.11)\end{array}$ & 18 \\
\hline $\begin{array}{c}\text { Co(II) } \\
\text { Complex }\end{array}$ & $\begin{array}{l}{\left[\mathrm{CoC}_{22} \mathrm{H}_{23}\right.} \\
\left.\mathrm{N}_{3} \mathrm{O}_{4} \mathrm{Cl}_{2}\right]\end{array}$ & 522.9 & $>300$ & 82 & $\begin{array}{c}50.19 \\
(50.48)\end{array}$ & $\begin{array}{c}4.30 \\
(4.39)\end{array}$ & $\begin{array}{c}8.00 \\
(8.03)\end{array}$ & $\begin{array}{c}11.17 \\
(11.26)\end{array}$ & 26 \\
\hline $\begin{array}{c}\mathrm{Zn}(\mathrm{II}) \\
\text { Complex }\end{array}$ & $\begin{array}{c}{\left[\mathrm{ZnC}_{22} \mathrm{H}_{25}\right.} \\
\left.\mathrm{N}_{3} \mathrm{O}_{5} \mathrm{Cl}\right]\end{array}$ & 511.5 & 230 & 60 & $\begin{array}{c}51.55 \\
(51.61)\end{array}$ & $\begin{array}{c}4.75 \\
(4.88)\end{array}$ & $\begin{array}{c}8.18 \\
(8.21)\end{array}$ & $\begin{array}{c}12.56 \\
(12.70)\end{array}$ & 16 \\
\hline $\begin{array}{l}\text { Mn(II) } \\
\text { Complex }\end{array}$ & $\begin{array}{c}{\left[\mathrm{MnC}_{22} \mathrm{H}_{23}\right.} \\
\left.\mathrm{N}_{3} \mathrm{O}_{4} \mathrm{Cl}_{2}\right]\end{array}$ & 518.5 & 265 & 55 & $\begin{array}{c}50.87 \\
(50.91)\end{array}$ & $\begin{array}{c}4.40 \\
(4.43)\end{array}$ & $\begin{array}{c}8.04 \\
(8.10)\end{array}$ & $\begin{array}{c}10.32 \\
(10.58)\end{array}$ & 8 \\
\hline $\begin{array}{c}\text { VO(IV) } \\
\text { Complex } \\
\end{array}$ & $\begin{array}{l}\mathrm{VO}\left[\mathrm{C}_{22} \mathrm{H}_{21}\right. \\
\left.\mathrm{N}_{3} \mathrm{O}_{3} \mathrm{SO}_{4}\right] \\
\end{array}$ & 538 & 270 & 80 & $\begin{array}{c}49.00 \\
(49.07) \\
\end{array}$ & $\begin{array}{c}3.85 \\
(3.90) \\
\end{array}$ & $\begin{array}{c}7.78 \\
(7.80) \\
\end{array}$ & $\begin{array}{c}9.55 \\
(9.58) \\
\end{array}$ & 12 \\
\hline
\end{tabular}

M.P $=$ Melting Points, $\Omega=$ Molar Conductance in $\mathrm{Ohm}^{-1} \mathrm{~cm}^{2} \mathrm{~mol}^{-1}$.

\section{Infrared spectra of the Schiff base and its complexes}

The IR spectra provide valuable information regarding the nature of functional group attached to the metal atom ${ }^{6}$. In order to study the bonding mode of Schiff base to the metal complexes, the IR spectrum of the free ligand was compared with the spectra of the complexes. The main IR bands and their assignments are listed in Table 2.

$>$ The IR band assignments of all metal complexes exhibit broad bands in the range of 3354 to $3423 \mathrm{~cm}^{-1}$ indicating the presence of coordinated water molecules ${ }^{7}$. 
A band at $1618 \mathrm{~cm}^{-1}$ in free Schiff base is due to $\mathrm{vC}=\mathrm{N}$ stretching vibration ${ }^{8}$.

$>$ But in complexes, the azomethine $(\mathrm{C}=\mathrm{N})$ frequency shows a down field or up field indicating coordination through $\mathrm{N}$-atom ${ }^{9}$.

$>$ IR spectra of the free ligand show a broadband around $3,350 \mathrm{~cm}^{-1}$ which can be attributed to $\mathrm{NH}$ stretching vibration of benzimidazole moiety.

$>$ The appearance of broadband around $3,400 \mathrm{~cm}^{-1}$. region was observed in the spectra of metal complexes indicating the presence of coordinated water molecules. Water molecules are coordinated, confirmed by the occurrence of additional band at $800-880 \mathrm{~cm}^{-1}$ arising due to $\mathrm{OH}$ rocking vibrations ${ }^{10}$ and $\nu \mathrm{M}-\mathrm{N}$ bands at $450-480 \mathrm{~cm}^{-1}$. In addition Vanadyl complex shows a band at $985 \mathrm{~cm}^{-1}$ corresponding to $\mathrm{V}=0$ frequency $^{11-14}$.

Table 2. Characteristics IR bands $\left(\mathrm{cm}^{-1}\right)$ of the compounds studied.

\begin{tabular}{ccccc}
\hline Compound & $v \mathrm{CH}=\mathrm{N}$ & $v \mathrm{M}-\mathrm{N}$ & $v \mathrm{M}-\mathrm{OH}$ & $v \mathrm{~V}=\mathrm{O}$ \\
\hline Ligand[BMEP] & 1618 & - & - & - \\
Cu-BMEP & 1604 & 435 & 3336,817 & - \\
Co-BMEP & 1608 & 435 & 3346,821 & - \\
Ni-BMEP & 1616 & 447 & 3390,848 & - \\
Zn-BMEP & 1585 & 452 & 3308,864 & - \\
Mn-BMEP & 1589 & 472 & 3335,829 & - \\
VO-BMEP & 1541 & 418 & 3325,827 & 985 \\
\hline
\end{tabular}

\section{Magnetic moments \& electronic spectral data}

The electronic spectral data was used to study the geometry the synthesized complexes based on the UV visible spectrum and the complexes were shown to have an octahedral geometry. The electronic spectral studies of the metal complexes of $\mathrm{Ni}(\mathrm{II}), \mathrm{Co}$ (II), $\mathrm{Cu}$ (II) $\mathrm{Zn}$ (II) $\mathrm{Mn}(\mathrm{II})$ and VO(IV) with Schiff bases were carried out in DMSO solution. The absorption spectrum of the Co(II) complex shows bands at 11,001, 27,548 and 29,498 cm-1 which are attributed to ${ }^{4} \mathrm{~T}_{1 \mathrm{~g}}(\mathrm{~F}) \rightarrow{ }^{4} \mathrm{~T}_{2 \mathrm{~g}}(\mathrm{~F})\left(\mathrm{v}_{1}\right),{ }^{4} \mathrm{~T}_{1 \mathrm{~g}}(\mathrm{~F}) \rightarrow{ }^{4} \mathrm{~A}_{2 \mathrm{~g}}(\mathrm{~F})\left(v_{1}\right)$ and ${ }^{4} \mathrm{~T}_{1 \mathrm{~g}}(\mathrm{P}) \rightarrow{ }^{4} \mathrm{~T}_{1 \mathrm{~g}}(\mathrm{~F})$ $\left(v_{3}\right)$ transitions respectively, that are characteristic of octahedral configuration ${ }^{15}$. The Co(II) has magnetic moment 4.28 B.M also suggest an octahedral geometry.

$\mathrm{Ni}(\mathrm{II})$ complex exhibits 3 electronic spectral bands at 22,371, 30,303 and 32,894 $\mathrm{cm}^{-1}$ can be assigned to ${ }^{3} \mathrm{~A}_{2 \mathrm{~g}} \rightarrow{ }^{3} \mathrm{~T}_{2 \mathrm{~g}}(\mathrm{~F})\left(\mathrm{v}_{1}\right),{ }^{3} \mathrm{~A}_{2 \mathrm{~g}} \rightarrow{ }^{3} \mathrm{~T}_{1 \mathrm{~g}}(\mathrm{~F})\left(\mathrm{v}_{2}\right)$ and ${ }^{3} \mathrm{~T}_{2 \mathrm{~g}} \rightarrow{ }^{3} \mathrm{~T}_{1 \mathrm{~g}}(\mathrm{P})\left(\mathrm{v}_{3}\right)$ in an octahedral field. The Ni(II) complex has magnetic moment $3.10 \mathrm{BM}$ also suggest an octahedral geometry. $\mathrm{Cu}(\mathrm{II})$ complex showed one broadband at $14,556 \mathrm{~cm}^{-1}$ mainly due to ${ }^{2} E_{g} \rightarrow{ }^{2} T_{2 g}$ transition suggesting octahedral geometry. The observed magnetic moment value for $\mathrm{Cu}(\mathrm{II})$ complex is $1.67 \mathrm{BM}$ suggestive of octahedral nature for the Complex.

Electronic spectra of $\mathrm{Mn}(\mathrm{II})$ complex display absorption bands at 34,482, 33,333 and $31,645 \mathrm{~cm}^{1}$, characteristic of octahedral geometry corresponding to ${ }^{6} \mathrm{~A}_{2 \mathrm{~g}} \rightarrow{ }^{4} \mathrm{~A}_{2 \mathrm{~g}}(\mathrm{P})$, ${ }^{6} \mathrm{~A}_{1 \mathrm{~g}} \rightarrow{ }^{4} \mathrm{~T}_{1 \mathrm{~g}}(\mathrm{P}),{ }^{6} \mathrm{~A}_{1 \mathrm{~g}} \rightarrow{ }^{4} \mathrm{E}_{\mathrm{g}}$ (D) transitions respectively and the magnetic moment value for $\mathrm{Mn}$ (II) complex is 5.47. We suggest octahedral nature.

The VO(IV) complex exhibited 3 transitions 28,409, 32894 and $34129 \mathrm{~cm}^{-1}$ which are assignable to ${ }^{2} \mathrm{E} \rightarrow{ }^{2} \mathrm{~B}_{2},{ }^{2} \mathrm{~B}_{1} \rightarrow{ }^{2} \mathrm{~B}_{2}$ and ${ }^{2} \mathrm{~A}_{1} \rightarrow{ }^{2} \mathrm{~B}_{2}$ respectively, that are characteristic of octahedral geometry. ${ }^{15}$ 
The $\mathrm{Zn}(\mathrm{II})$ complex shows no d-d bands as is expected for a $\mathrm{d}^{10}$ system and was found to be diamagnetic in nature and on the basis of analytical, conductance and spectral data, it is assigned an octahedral geometry.

Table 3. Magnetic moments \& electronic spectral data for the complexes.

\begin{tabular}{cccc}
\hline Complex & $\mu_{\text {eff }}$ B.M & Frequency, cm & Assignments \\
\hline Cu-BMEP & 1.67 & 14,556 & ${ }^{2} \mathrm{E}_{\mathrm{g}} \rightarrow{ }^{2} \mathrm{~T}_{2 \mathrm{~g}}$ \\
& & 11,001 & ${ }^{4} \mathrm{~T}_{1 \mathrm{~g}}(\mathrm{~F}) \rightarrow{ }^{4} \mathrm{~T}_{2 \mathrm{~g}}(\mathrm{~F})$ \\
Co-BMEP & 4.28 & 27,548 & ${ }^{4} \mathrm{~T}_{1 \mathrm{~g}}(\mathrm{~F}) \rightarrow{ }^{4} \mathrm{~A}_{2 \mathrm{~g}}(\mathrm{~F})$ \\
& & 29,498 & ${ }^{4} \mathrm{~T}_{1 \mathrm{~g}}(\mathrm{P}) \rightarrow{ }^{4} \mathrm{~T}_{1 \mathrm{~g}}(\mathrm{~F})$ \\
Ni-BMEP & 3.1 & 22,371 & ${ }^{3} \mathrm{~A}_{2 \mathrm{~g}} \rightarrow{ }^{3} \mathrm{~T}_{2 \mathrm{~g}}(\mathrm{~F})$ \\
& & 30,303 & ${ }^{3} \mathrm{~A}_{2 \mathrm{~g}} \rightarrow \mathrm{T}_{1 \mathrm{~g}}(\mathrm{~F})$ \\
VO-BMEP & 1.6 & 28,894 & ${ }^{3} \mathrm{~T}_{2 \mathrm{~g}} \rightarrow{ }^{3} \mathrm{~T}_{1 \mathrm{~g}}(\mathrm{P})$ \\
& & 32894 & ${ }^{2} \mathrm{E} \rightarrow{ }^{2} \mathrm{~B}_{2}$ \\
& & 34129 & ${ }^{2} \mathrm{~B}_{1} \rightarrow{ }^{2} \mathrm{~B}_{2}$ \\
Mn-BMEP & \multirow{3}{*}{5.47} & 34,482 & ${ }^{2} \mathrm{~A}_{1} \rightarrow{ }^{2} \mathrm{~B}_{2}$ \\
& & 33,333 & ${ }^{6} \mathrm{~A}_{2 \mathrm{~g}} \rightarrow{ }^{4} \mathrm{~A}_{2 \mathrm{~g}}(\mathrm{P})$ \\
Zn-BMEP & Diamagnetic & 31,645 & ${ }^{6} \mathrm{~A}_{1 \mathrm{~g}} \rightarrow{ }^{4} \mathrm{~T}_{1 \mathrm{~g}}(\mathrm{P})$ \\
\hline
\end{tabular}

\section{${ }^{1}$ H NMR spectra}

The ${ }^{1} \mathrm{H}$ NMR spectrum of the ligand in $\mathrm{CDCl}_{3}$ shows the following signals given in Table 4 . The sharp singlet at 7.3 attributed to azomethine proton $(-\mathrm{CH}=\mathrm{N}-)$ confirms the formation of the ligand as proposed.

Table 4. ${ }^{1} \mathrm{H}$ NMR data of Schiff base.

\begin{tabular}{cc}
\hline Chemical Shift, $\delta, \mathrm{ppm}$ & Functional Group assigned \\
\hline $7.3(1 \mathrm{H}, \mathrm{s})$ & $-\mathrm{CH}=\mathrm{N}-$ \\
$10(1 \mathrm{H}, \mathrm{s})$ & $-\mathrm{NH}-$ \\
$6.9-7.4$ & Phenyl ring \\
7.9 & Benzimidazole \\
\hline
\end{tabular}

\section{ESR spectra of $\mathrm{Cu}(\mathrm{II})$ complex}

The ESR spectral studies of $\mathrm{Cu}(\mathrm{II})$ complex provide information of the metal ion environment. The ESR spectrum of $\mathrm{Cu}$ (II) was recorded in DMSO at Liquid Nitrogen temperature (LNT). This complex in frozen state at $77 \mathrm{~K}$ shows four slightly resolved peaks low intensities in the low field region and one intense peak in the high field region.

The $g$ values of the complex are $g \|(2.324)>g \perp(2.021)>2.0023$, indicating that the unpaired electron in the ground state of $\mathrm{Cu}(\mathrm{II})$ is predominantly in $\mathrm{dx} 2-\mathrm{y} 2$. The value of exchange interaction term $\mathrm{G}$, estimated from the following expression is 2.73 .

$$
\mathrm{G}=g \|-2.0023 / g \perp-2.0023
$$

If $\mathrm{G}>4.0$, the local tetragonal axes are aligned parallel or only slightly misaligned. If $\mathrm{G}<4.0$, significant exchange coupling is present and misalignment is appreciable. The observed value for the exchange interaction term $G$ suggests that the complex has distorted 
octahedral geometry and the Schiff base ligand forming $\mathrm{Cu}(\mathrm{II})$ complex is considered as strong field ligand.

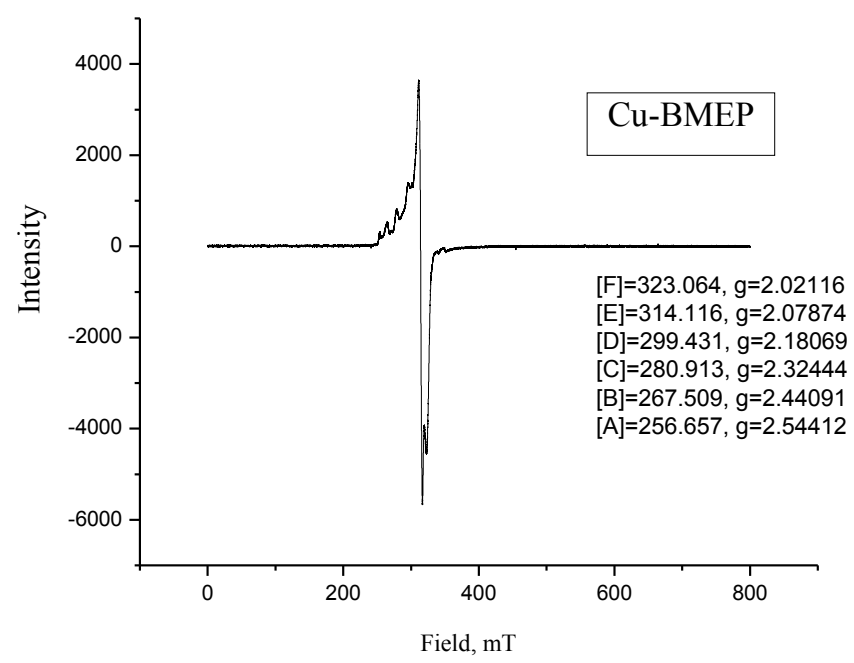

Figure 2

\section{Molecular modeling studies}

The possible geometris of metal complexes were evaluated using the molecular calculation with Argus lab 4.0.1 version software. The metal complexes were built and geometry optimization was done using molecular mechanics uniform force field (UFF) method. The molecular modeling pictures and the energies of metal complexes are shown in Figure 4.

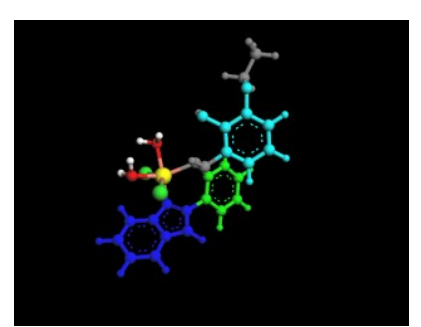

$\left.\mathrm{Cu}(\mathrm{BMEP})\left(\mathrm{H}_{2} \mathrm{O}\right)_{2} \mathrm{Cl}_{2}\right]$ $(-12.24 \mathrm{~K} . \mathrm{Cal} / \mathrm{mol})$

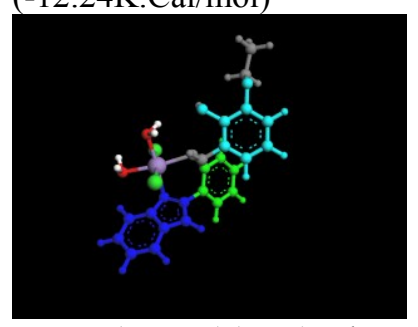

$\left[\mathrm{Mn}(\mathrm{BMEP})\left(\mathrm{H}_{2} \mathrm{O}\right)_{2} \mathrm{Cl}\right]$ (-20.8K.Cal $/ \mathrm{mol})$

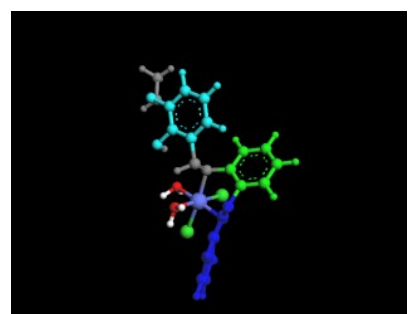

[Co(BMEP) $\left.\left(\mathrm{H}_{2} \mathrm{O}\right)_{2} \mathrm{Cl}_{2}\right]$ $(-184.43 \mathrm{~K} . \mathrm{Cal} / \mathrm{mol})$

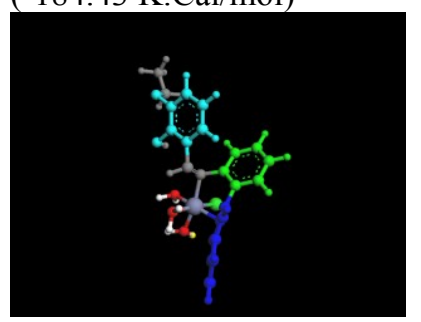

[Zn(BMEP) $\left.\left(\mathrm{H}_{2} \mathrm{O}\right)_{3} \mathrm{Cl}\right]$ (--35.53 K.Cal $/ \mathrm{mol})$

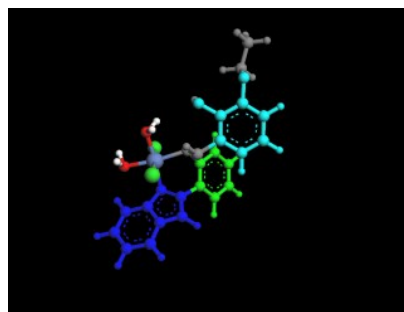

$\left[\mathrm{Ni}(\mathrm{BMEP})\left(\mathrm{H}_{2} \mathrm{O}\right)_{2} \mathrm{Cl}_{2}\right]$ $(-189 \mathrm{~K} . \mathrm{Cal} / \mathrm{mol})$

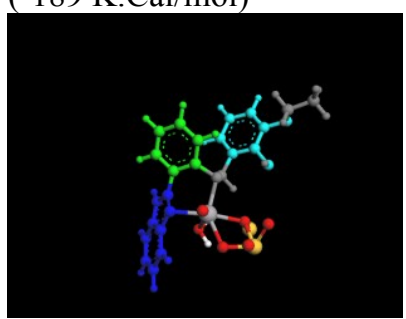

[VO(BMEP $\left.)\left(\mathrm{H}_{2} \mathrm{O}\right) \mathrm{SO}_{4}\right]$ $(-349 \mathrm{~K} . \mathrm{Cal} / \mathrm{mol})$

Figure 3. Molecular modeling structures for metal complexes. 


\section{Antibacterial studies}

The synthesized Schiff bases and their corresponding metal complexes were screened against Escherischia.Coli, Staphylococcus aureus, Bacillus.subtilis and Pseudomonas. Fluorescence to assess their potential as antimicrobial agent by diffusion method ${ }^{16}$.

A comparative study of growth inhibition zones values of Schiff base and its complexes indicate that metal complexes exhibit higher anti-bacterial activity than the free ligands and the same is indicated from the results given in the Table 6 . This is probably due the greater lipophilic nature of the complexes. Such increased activity of the metal chelates can be explained on the basis of Overtone's concept and Tweedy's chelation theory ${ }^{17}$. According to overtone's concept of cell permeability, the lipid membrane that surrounds the cell favors the passage of only lipid soluble materials due to which liposolubility is an important factor which controls the anti-microbial activity. On chelation, the polarity of the metal ion will be reduced to a greater extent due to overlap of the ligand orbital and partial sharing of positive charge of metal ion with donor groups ${ }^{18,19}$. Further, it increases the delocalization of the $\pi$ electrons over the whole chelate ring and enhances the lipophilicity of the complex. This increased lipophilicity enhances the penetration of the complexes into lipid membrane and the blocks the metal binding sites on enzymes of microorganisms ${ }^{20}$. These metal complexes also disturb the respiration process of the cell and thus block the synthesis of proteins, which restricts further growth of the organism ${ }^{21}$.

The diffusion method requires filter paper disk, the medium used is Muller-Hinton agar with $2 \%$ of glucose and diameter of inhibition zone is visually read at $24 \mathrm{~h}$ after incubation at $37{ }^{\circ} \mathrm{C}$. The compounds are added on to the filter paper containing this medium. The antimicrobial activity was estimated on the seeded agar plates. Streptomycin was used as standard.DMSO was used as solvent control. The zones of inhibition based upon zone size around the discs were measured. The measured zone of inhibition against the growth of various microorganisms is listed in Table 5. It is found that metal complexes have higher anti-bacterial activity than the free ligand. Hence the complexation increases the microbial activity $^{22}$. Such increased activity of metal complexes was explained on the bases of Chelation $^{23}$.

Table 5. Growth Inhibition Zone of Microbes in $\mathrm{mm}$.

\begin{tabular}{ccccc}
\hline Compound & E.coli & P.fluorescence & B.subitilis & S.aureus \\
\hline Schiff base & 9 & 8 & 8 & 10 \\
Cu(II) Complex & 17 & 10 & 10 & 14 \\
Co(II) Complex & 15 & 11 & 10 & 15 \\
Ni(II) Complex & 12 & 8 & 11 & 11 \\
Mn(II) Complex & 5 & 11 & 9 & 10 \\
VO(IV) Complex & 14 & 11 & 10 & 11 \\
Zn(II) Complex & 16 & 18 & 17 & 20 \\
\hline
\end{tabular}

\section{Conclusion}

The BMEP ligand and its metal complexes of $\mathrm{Ni}(\mathrm{II}), \mathrm{Co}(\mathrm{II}) \mathrm{Cu}(\mathrm{II}), \mathrm{Zn}(\mathrm{II}) \mathrm{Mn}(\mathrm{II})$ and VO(IV) have been structurally characterized. The analytical data show that the metal Ligand stoichiometry in all these complexes is $1: 1$. All the complexes are non-electrolytes in DMSO. The spectral data show that the ligand is bidentate which coordinates through the tertiary nitrogen of the imidazole ring, the exocyclic imine nitrogen of 2-(2-amino phenyl) 
1- $H$-benzimidazole ${ }^{24}$. Based on analytical, conductance, magnetic and Electronic spectral data, all these complexes are assigned to be in octahedral geometry. Biological studies of these complexes reveal that these complexes show better activity compared to the ligand.

\section{References}

1. Yamada S, Coord Chem Rev., 1999, 537, 190-192

2. Singh S, Das s and Dhakarey R, E-J Chem., 2009, 6(1), 99-105

3. Raman N,syed Ali Fathima S and Dhaveethu Raja, J Serb Chem Soc., 2008, 73(11), 1063-1071

4. Goker.H, Alp M and Yildiz S, Molecules, 2005, 10,1377

5. Patzold.F, Zener F, Heyer.J H and Nichlas H J, Synthetic Commun., 1992, 22, 281.

6. $\quad$ Suresh M S and Prakash V, Int J Current Res., 2011, 3(2).

7. Jezowska B, Lisowski J and Chmielewski P, Polyhedron, 68-75

8. Seema Varghese, RJPBCS.2010,2,347

9. Prashanthi Y and Shivraj, J Sci Res., 2010, 2(1), 114.

10. Poonam. Deshmukh, Amit R Yaul, Jayashree, Bhajane.N and Aanad J Aswan. World J Chem., 2010, 5(1), 57.

11. Mozaffar Asadia, Mohammad Hadi Ghateea, Susan Torabia, Khosro Mohammadib and Fatemeh Moosavia, J Chem Sci., 2010, 122, 539

12. Hamdi Temel, Umit Cakir and Ibrahim Ugras.I, Synth React Inorg Metal Org Chem.., 2004, 34, 819

13. Nakamoto K, Infrared and Raman spectra of inorganic and coordination compounds, part A and Part B, New York, NY USA; John Wiley \& sons, 1998

14. Silverstein R M, Bassler G C and Morril T C, Spectroscopic identification of organic compds, $5^{\text {th }}$ Edition, Newyork, NY, USA, John Wiley \& sons; 1991.

15. Lever, A.B.P.Inorganic electrospectra, Elsevier, Newyork, 1984.

16. Zotta V, (Ed.), Chimie farmaceutica, Medicala; Bucuresti. 1985.67.

17. Tweedy B G, Phyto Pathology., 1964, 55, 910

18. Kralova K, Kissova K, Svajlenova O and Vanco J, Chem Pap., 2000, 58(5), 361.

19. Parekh J, Inamdhar P, Nair R, Baluja S and Chanda S, J Serb Chem Soc., 2005, 70, 1161.

20. Vaghasia Y, Nair R, Soni M, Baluja S Chanda S, J Serb Chem Soc., 2004, 69, 991.

21. Raman N, Res J Chem Environ., 2005, 4, 9.

22. Anjaneyula Y and Roa P P, Synth React Inorg Met Org Chem., 1986, 26, 257.

23. Thimmaiah K N, Lloyd W D and Chandrappa G T, Inorg Chim Acta, 1985, 81, 106.

24. Pilar Souza, Jose A. Garcia- Vazquez and Masagner J R, Trans Met Chem., 1985, 10, 410-412. 


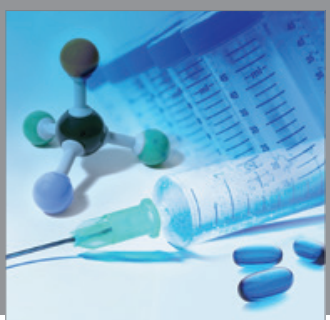

International Journal of

Medicinal Chemistry

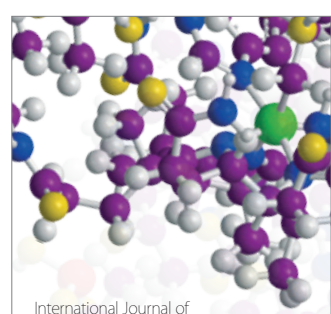

Carbohydrate Chemistry

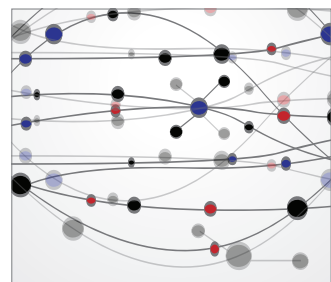

The Scientific World Journal
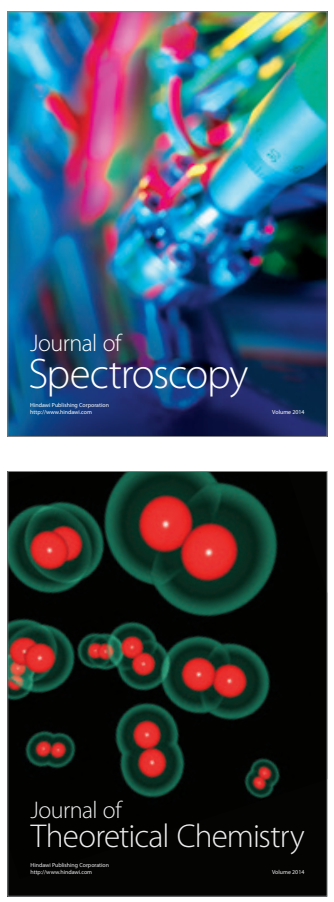
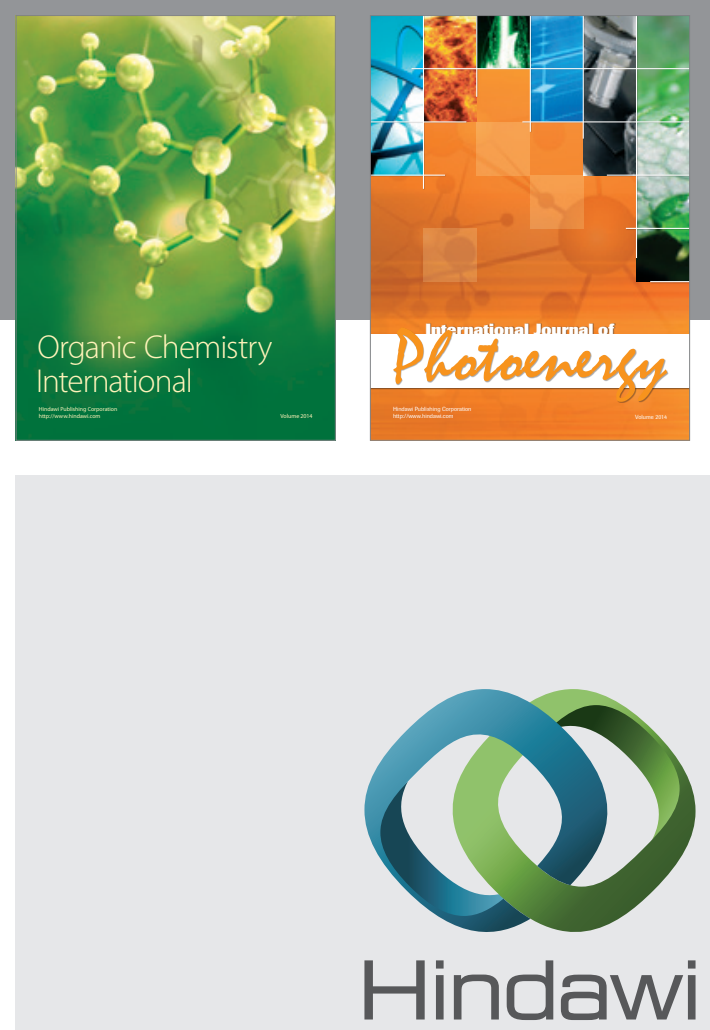

Submit your manuscripts at

http://www.hindawi.com
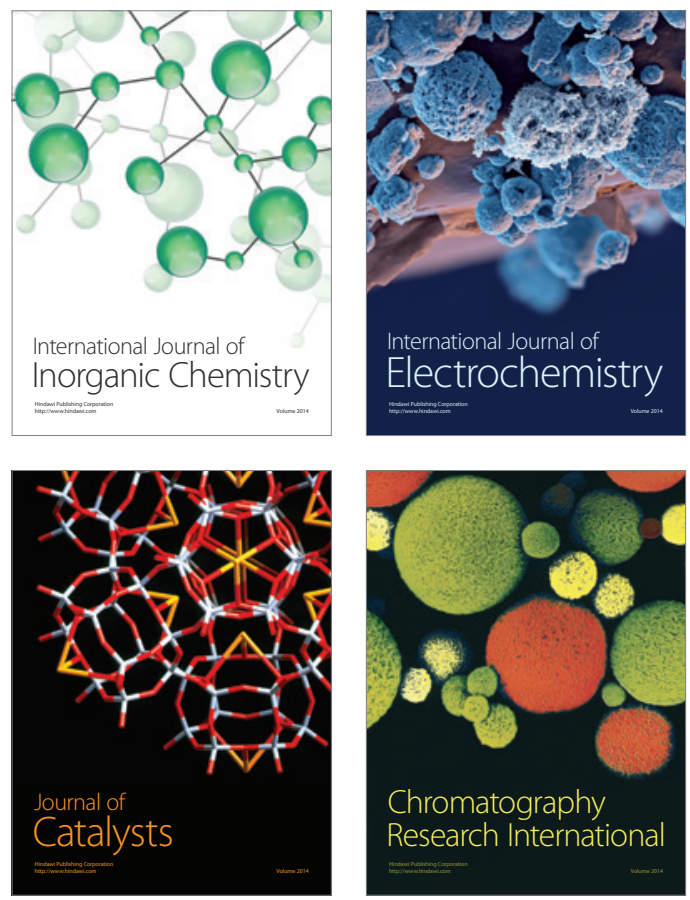
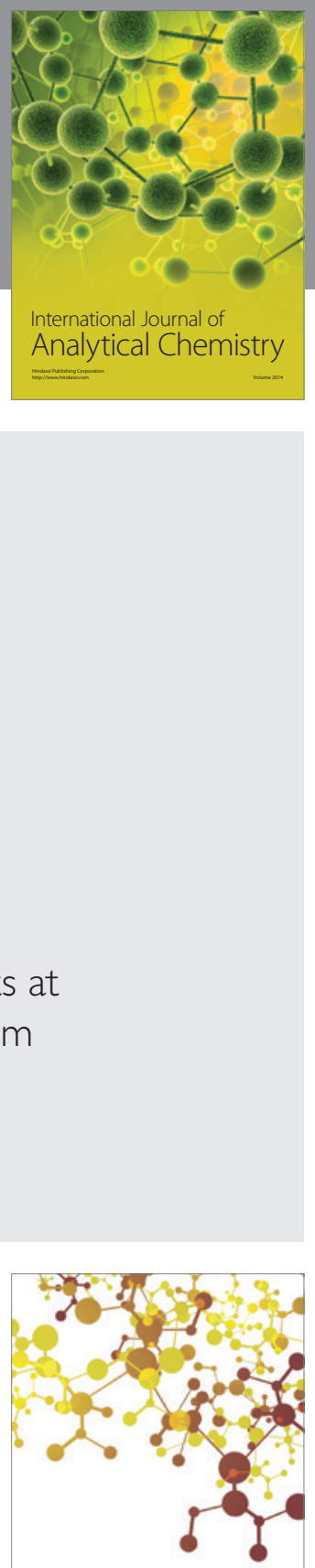

Journal of

Applied Chemistry
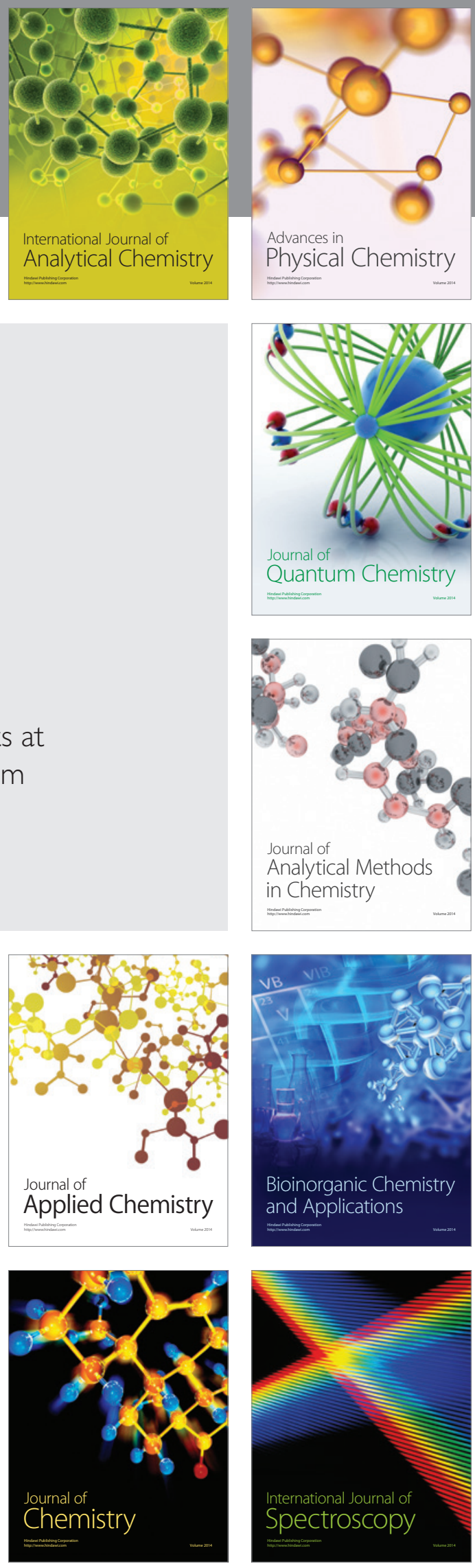